\title{
The Role of SPEs in the Enron Scandal and Its Implications for China
}

\author{
Shihan Liu ${ }^{1, *, a, \dagger}$ Lingyuan $\mathrm{Lu}^{2, *}, \mathrm{~b}, \dagger$ Yidi Wu ${ }^{3, *, c, \dagger}$ \\ ${ }^{1}$ Herberger School of Business, St. Cloud State University, Minnesota, MN56301, USA \\ ${ }^{2}$ School of Information Management and Statistics, Hubei University of Economics, Hubei, 430205, China \\ ${ }^{3}$ International Business School, Beijing Foreign Studies University, Beijing, 100089, China

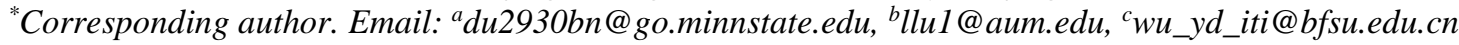 \\ These authors contributed equally.
}

\begin{abstract}
Special purpose entity (SPE) is a type of financial instrument that can legally help companies reduce debt, raise capital, reduce stress, and reduce losses and is widely applied in U.S. companies. However, from Enron Scandal, SPE may also let firms be exposed to certain risks. This paper aims to study the role of SPE in the Enron financial frauds. We also examine the application of SPE in the Chinese market and discuss its future development. A case study was conducted on Enron, and we also studied the current applications of the existing SPEs in China. This paper finds that SPEs did facilitate Enron's growth and contributed to its failure because SPE may lower the cost of financial misreporting. Therefore, we suggest that more subtle regulations should be imposed on SPE. We also review the Chinese SPEs and suggest that relevant regulations should be applied to protect investors' interests.
\end{abstract}

Keywords: Special purpose entity, Enron, financial frauds, Sarbanes-Oxley Act.

\section{INTRODUCTION}

As important financial tools, special purpose entities (SPEs) have served many legitimate economic purposes, such as off-balance sheet financing, risk isolation, operating lease, and asset securitization. However, in the early 2000s Enron Scandal, SPE was used to conceal losses from the financial statements, which leads to an unlimited expansion of the company. Nowadays, more and more companies in China started using SPEs. Studying the risk of SPE and related regulatory issues in the Chinese market context is very important for two main reasons. First, the Chinese financial and accounting industry has not yet issued regulations for the use of SPEs. Second, special purpose entities are often operated cross-border. If the Chinese market doesn't know how to use them properly, financial risks may accumulate in markets at home and abroad.

In this paper, we explore what role SPE played in the Enron financial frauds incident and how it may be used improperly. And, for China, how to better regulate the use of SPE to add vitality to the financial market.

Many studies have done an in-depth analysis of the reasons leading to Enron's demise. The reasons can be mainly divided into two dimensions-auditing and accounting issues. For the auditing issue, the lack of independence explains all, while there are four improper operations for the accounting issue. First, the overestimation of profits and underestimation of liabilities through SPE. Inappropriate use of SPE to exclude from the financial statement while Enron was not qualified to do so. Second, overestimate assets and shareholders' equity by showing empty notes receivable. Third, manipulate profits through limited partnerships. Enron uses financial innovations, including limited partnership, to raise funds and hedge risks. Fourth, use the partnership network to organize self-trading and conceal huge losses [1-3].

The Enron scandal has caused the United States to reflect on its accounting and auditing standards. The Financial Accounting Standards Board (FASB) has also begun to review whether the US accounting standards are adapted to the ever-changing economic environment. The Sarbanes-Oxley Act of 2002 increased the supervision of auditors. The fair value measurement standards were introduced by the Financial Accounting Standards Committee in 2006. However, the subprime mortgage crisis that broke out in 2008 proved it to be useless and harmful. Zhou argues 
that the rules of the accounting industry are always in the hands of those who have vested interests in the securities industry and are divorced from legal principles. Solutions to this problem can be: First, return to "accounting according to legal facts" and truthfully disclose. Second, create a securities information disclosure rule parallel to the law and relies on private authorities to implement securities information disclosure rules [4]. We expect to find more evidence to prove that certain accounting treatment is conducive to enterprise development. At the same time, the system must speed up the adjustment.

In other findings, Enron set up hundreds of SPEs, which not seems to comply with relevant accounting principles and regulations. However, Enron does not need to enter assets and liabilities into the account through them but lacks substantial transactions, so it is a kind of accounting fraud [5]. The SPE Enron used to perform accounting treatment called "special purpose entity", it is a fenced organization having limited predefined purposes and a legal personality [6]. The legal domain views SPEs mostly as off-balance sheet instruments enabling tax optimization and balance sheet management. Evidence proves that the use of SPEs contributes to tax avoidance to save cash from research and development (R\&D), depreciable assets, net operating loss carryforwards, intangible assets, foreign operations, and tax havens [7]. Besides, SPE does more than just avoid taxes and risk isolation, operating lease, and asset securitization. Because of these functions, the companies using SPEs, implementing the Sarbanes Oxley Act in conjunction with FIN 46, made no significant difference in the average number of SPE's used [8]. We believe that the consolidation and disclosure requirements concerning SPEs will continue to evolve. However, since SPEs do serve legitimate business purposes, off-balance-sheet entities are permitted as a matter of policy.

Our paper contributes to the literature in the following ways. First, it articulates the role that the SPE plays in Enron's financial statement fraud. Enron used a series of complex operations to expand the company's size, which eventually led to bankruptcy [1]. We only focus on the transaction between Enron and SPEs to learn how the existing legislation restricts SPE. Second, our paper has a policy implication for the Chinese market. We firmly believe that the restricted adoption of SPE broadens the financing channels of enterprises. But the fact is, few provisions on the establishing conditions of SPEs, consolidation rules, etc., are made.

The rest of the paper is organized as follows. Section 2 analyzes the role of SPE in the Enron case. Section 3 describes SPE development in China, including the comparison of Chinese regulations and international accounting standards. The final section concludes and provides policy suggestions on SPEs for the Chinese market.

\section{THE ROLE OF SPEIN THE ENRON CASE}

To understand the whole process of the incident and the role SPE plays in the Enron bankruptcy, we need to start with the background. In the 1990s, great changes have taken place in the economy's growth in the United States. Enron also complied with this trend and gradually began its global expansion, expanding its business and investment in more than 40 countries and regions. Meanwhile, Enron bought assets and rebuilt them, such as pipelines and power plants, and then developed wholesale or retail business with these assets as the core and expanded its business types from natural gas energy to various industries. But the following problems gradually emerged. These huge investments of Enron cannot get profits in the short term, but Enron firmly believes that these investments have lucrative long-term returns [9]. In addition, the failure of some subsequent investments, such as the water bank, has caused adverse effects on Enron's short-term cash flow.

Under this circumstance, to keep revealing the company's prosperity and maintain the stock price, Enron starts to use SPE in another way to fake their balance sheets. Since the 1990s, Enron has started to use SPE in its numerous business contracts. Such as synthetic lease transactions, selling financial assets, stocks of Enron, or long-term contracts used to buy Enron stocks to SPE. Some assets transfers are included likewise. Using this method, Enron can increase cash flow through off-balance-sheet financing to compensate for the shortage of cash flow caused by large-scale expansion. And avoid the shortcomings of issuing more stocks, which will reduce the shareholders' equity. At the same time, it also helps Enron expand the emerging business and adjust the industrial structure to occupy the market quickly.

But in this way, the fund is still insufficient to afford Enron's expansion. At the same time, to create the illusion that the company is still prosperous and attract investors to continue to purchase Enron's stock, Enron, who is familiar with financial skills, began to turn SPE into a tool to inflate profits and hide liabilities. The purpose of SPE itself is to isolate the risk. And the key point that makes it a tool of fraud is that the sponsor company actually controls SPE but still does not show it in the consolidated statements [10].

Enron's main ways of operating SPE are as follows: First, depositing the stocks to the trust investment company which own the whole negotiated price. Second, these stocks are used to provide a guarantee for an Enron-controlled SPE. In this way, Enron makes the corporate bonds issued by the SPE company more 
reliable. Investors will be convinced by this guarantee and have the willingness to invest in these bonds. Then, SPE obtains a small amount of cash capital investment (at least 3\%) from external investors, who have no profitable connection between the SPE sponsor and manager. But Enron, however, takes many of these SPEs into their own control. Substantial of them actually are Enron's internal executives. Some of them even are the Enron managers. At the same time, for those external inventors who are not the employees of Enron, to make the equity of these investors meet the $3 \%$ criterion investment in legal form, Enron privately signed undisclosed compensation contracts with these investors, providing some cash or other guarantees [11]. In addition, Enron also provides cash, Enron stocks, or other forms of guarantee for some SPE bank loans; They also used SPE to sell problematic investments, such as stocks of some overseas energy facilities and split stocks of Enron. According to the law, if the external investor has an interesting relationship with the sponsor of SPE, the funds obtained through the offbalance-sheet financing of SPE should be shown in the balance sheet. But Enron conceals its interest relationship with these external investors and still does not reveal these assets and liabilities in the balance sheet. Meanwhile, through these 'external' investors,
Enron itself controls these SPE companies. After all, preparation steps were completed, SPE raises a large amount of cash by issuing corporate bonds guaranteed by Enron stocks. By issuing these bonds, SPE can achieve the purpose of funding. And even if the amount of funding isn't achieving the company's demand and results in a failure, the company won't lose much money as the company invests the project directly. At last, SPE and Enron set up a joint venture company with $50 \%$ equity. To obtain another $50 \%$ percent of equity, Enron will use its assets (always an abroad investment full of debt) to make an exchange. If there are more SPE companies, the first company will own $50 \%$ equity of the second SPE company and aim to acquire more equity, and so on. According to this, Enron formed many SPE companies. Through the establishment of a complex company system and elongation of the control chain, Enron left the debt in the account of subsidiaries. And the profit was displayed in the account of the parent company. By finishing all processes above, Enron successfully achieves the purpose of manipulating profits and hiding debt. According to the investigation, which some researchers finished, Table 1 shows how much debt Enron hid and profit Enron made up [1].

Table 1. Financial statement of Enron from 1997 to 2000

\begin{tabular}{|c|c|c|c|c|c|}
\hline \multirow{2}{*}{ Project } & \multicolumn{4}{|l|}{ Year } & \multirow{2}{*}{ Total } \\
\hline & 1997 & 1998 & 1999 & 2000 & \\
\hline \multicolumn{6}{|l|}{ Net income } \\
\hline Net income before the adjustment & 1.05 & 7. 03 & 8. 93 & 9. 79 & 26. 80 \\
\hline Less: Decreased profits due to restructuring & 0.45 & 1.07 & 2. 48 & 0.99 & 4. 99 \\
\hline Profit adjusted by audit & 0.51 & 0.06 & 0.02 & 0.33 & 0.92 \\
\hline Net income after the adjustment & 0.09 & 5. 90 & 6. 43 & 8. 47 & 20. 89 \\
\hline Adjusted net income accounted for the pre-adjusted ratio & 8. $6 \%$ & $83.9 \%$ & $72.0 \%$ & $86.5 \%$ & 77. $9 \%$ \\
\hline \multicolumn{6}{|l|}{ Total liability } \\
\hline Total liability before the adjustment & 62.54 & 73. 57 & 81.52 & 100. 23 & - \\
\hline Add: Increased liability due to restructuring & 7. 11 & 5. 61 & 6.85 & 6. 28 & - \\
\hline Total liability after the adjustment & 69.65 & 79. 18 & 88. 37 & 106. 51 & - \\
\hline Adjusted liability accounted for the pre-adjusted ratio & $111.3 \%$ & 132. $1 \%$ & 108. $4 \%$ & 106. $3 \%$ & - \\
\hline
\end{tabular}

Unit: \$ million

Through operations above, Enron can use SPEs to raise funds to pay its debt by issuing bonds. But the problem with this approach is that these debts are only formally transferred to SPE. Once the value of the assets sold by Enron declines, Enron will have to make up for it by issuing new stocks. However, the decline of stock price makes it more and more difficult to repay the debt, which eventually leads to the exposure of Enron's debt [10].

\section{SPE IN CHINA}

It is rare to find a Fortune 500 company in the United States that does not use SPEs, which are inherently designed to isolate and hedge financial risk 
and are fundamentally designed to facilitate the sale of specific financial assets owned by the originating company. However, the bankruptcy of Enron, once one of the world's largest energy, goods and services companies, completely shattered investor confidence in the capital markets. The U.S. Congress and the government accelerated the passage of the SarbanesOxley Act of 2002 to regulate and change this situation. This section will examine the accounting standards related to Enron and its aftermath as an example and the related developments in China and future expectations.

With the development and opening of our economy, various companies in China and domestic accounting firms are more and more involved in international business. The Enron incident and the Sarbanes-Oxley Act of 2002 have also impacted Chinese accounting firms and accounting standards and related legal provisions. Its bill provides that the Public Company Accounting Oversight Board has the authority to determine that foreign accounting firms that do not directly issue an audit report but play a substantial role in issuing the company's audit report should be treated the same as U.S. domestic accounting firms. This provision means that our accounting firm issues an audit report for a U.S. public company or substantially performs the audit of financial statements. This means that if a foreign accounting firm issues an audit report for a public company in the United States or substantially performs a substantial portion of the audit work and thus plays a material role in the issuance of the audit report, then the firm is subject to the SarbanesOxley Act of 2002 and the relevant rules of the Public Company Accounting Oversight Board and the Securities and Exchange Commission, and is subject to the duties, obligations, and liabilities outlined in those laws and regulations [12].

This regulation is challenging for Chinese accounting firms because the requirements for accounting vary from country to country, and the laws and regulations regarding this are different as well. It is a matter of exploration to meet the requirements of foreign companies while satisfying the laws and regulations of China. Since there is no direct regulation on SPE in China, we can only analyze and explore based on the U.S. regulations on SPE. At the same time, we need to pay attention to the point that in June 1998, the IASB issued IAS Interpretation No. 12, which considers that SPEs should be included in the scope of consolidated accounting statements if the entity substantially controls them. And IAS 27: Consolidated Financial Statements means financial statements prepared by treating an enterprise group as if it were a single economic entity. This standard clearly stipulates that SPEs may no longer be heaven for major corporations to avoid taxes as they were before. However, the purpose of IAS is to standardize accounting practices on an international scale. It does not directly bind the accounting activities of individual countries but rather influences them by incorporating them into national accounting standards systems. If the country does not adopt IAS, then the standard does not substantially bind the company's operations. With the progress of society and the opening of the economy, SPE has developed in China. According to the information, there are about three types of SPEs in China. The first type comes along with the development of asset securitization. Asset securitization is a great financial innovation because of its unparalleled role in solving the liquidity of non-performing assets and enhancing the liquidity of assets. In China, with the introduction of asset securitization, SPEs have emerged and will develop with the securitization process. The second is the gradual evolution of listed companies and their related parties. Most of the listed companies in China are born from the restructuring of state-owned enterprises, forming listed companies, parent companies, and other related enterprises. It is common for listed companies to manipulate profits and take up funds by using related party transactions. In view of this, the accounting standard-setting bodies have deepened their research in this area and constantly updated the guidelines on related party transactions to curb the phenomenon mentioned above. It is foreseeable that the room for manipulating profits by using related party transactions will become smaller and smaller. Some small listed companies will likely use related companies to set up SPEs and "put old wine in new bottles" (an old Chinese saying) to find a regulatory vacuum [13].

The last one is Chinese enterprises avoiding taxes overseas. Unlike Enron's purpose of inflating profits and hiding debts, many Chinese enterprises use SPE to transfer profits to achieve tax avoidance. Fig. 1 shows that Company A will put all the substantial operations of the enterprise in SPE100, and the profit will also stay in SPE100. Because SPE100 is set up in tax havens such as the Cayman Islands, the tax they need to pay is much lower than in China.

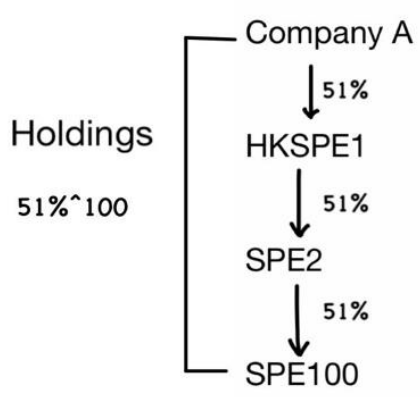

Figure 1 The equity structure of how to establish an SPE.

Many companies use this last method, and most of them are domiciled in Bermuda, Cayman Islands, 
British Virgin Islands, etc. The largest advantage of registering in these locations is that the company enjoys very low or no taxation. So, while it is good for the business to have an SPE, the pure purpose of an SPE is to raise capital for the business, not to avoid taxes and, like Enron, to embellish financial statements and cover up debt.

Therefore, we recommend that Chinese companies that have already used this SPE to avoid tax should stop and minimize this practice. Because its behavior will lead to a reduction in the taxes, we should pay to the Chinese government, and in the long run, it will affect China's national construction and normal operations. We also propose that Chinese companies that want to use SPE for financing in the future should comply with industry guidelines and make their balance sheets as transparent as possible. At the same time, with the process of globalization and China's rapid move towards internationalization, Chinese laws and regulations, and accounting standards need to change.

\section{CONCLUSION}

According to the research and discussion above, some conclusions have been drawn. First, SPE does have its intrinsic advantages. SPE can legally help enterprises carry out off-balance-sheet financing and risk hedging operations as a financial tool. By reducing the pressure of liability, enterprises can accumulate some cash flows in the short term to have some funds for other investments and increase the net income. At the same time, it can transfer some high-risk projects to SPE for operation. Even if there is a loss in the project's operation, it can also prevent the company from assuming considerable losses. And it also gives conveniences to the enterprise which wants to quickly enter a market or adjust its business structures. For it cohere the connection between enterprises and investors and accelerate the flowing of the social fund.

Second, through the Enron case, there are also some problems in the application of SPE. According to existing laws, if the SPE has no interest connection with the sponsor, it can only possess financial assets within the scope applied at the time of establishment. But in this case, it is clear that Enron's fraud is mainly due to the problem of consolidating the balance sheet. Therefore, the regulator should force the SPE, which violates rules to reveal the operation in the sponsor's balance sheet.

Last, through the Enron case, laws about SPE use need to be improved, and the supervision of the SPE should be more rigorous. All governments should learn from the lessons of the Enron incident and have a good understanding of international accounting standards. To effectively promote the formulation and improvement of
SPE laws and domestic accounting standards and increase the punishment for violations of SPE.

For China, although some enterprises have begun to use SPE, it is not widely used at present. Moreover, the relevant domestic laws only involve the type of trust SPE, and the relevant provisions for the type of company SPE have not yet been established. There are no criteria for the consolidated financial statements of SPE. Therefore, it is significant to improve the laws of SPE and make them more comprehensive. At the same time, audit institutions need to conduct a more stringent audit on the internal structure of SPE to prevent external investors from having interest connections with SPE sponsors. At the same time, we should pay attention to not only the arrangement of the system but also allaround honesty education. When huge economic interests collide with serious moral norms, only the successful honesty education can make the balance tend to the latter.

\section{REFERENCES}

[1] Ge Jiashu, Huang Shizhong." Critical Review of Enron Event-A Thorough Analysis of Enron's Accounting and Auditing Issues." Accounting Research $.02(2002): 3-11+65$ doi:CNKI:SUN:KJYJ.0.2002-02-000.

[2] C.Richard Baker and Rick Hayes."Reflecting form over substance: the case of Enron Corp.." Critical Perspectives on Accounting 15.6(2002): doi:10.1016/j.cpa.2002.08.001.

[3] Uma V. Sridharan, et al."Financial Statement Transparency and Auditor Responsibility: Enron and Andersen." International Journal of Auditing 6.3(2002): doi:10.1111/j.10991123.2002.tb00018.x.

[4] Zhou Hua." Enron Event, Subprime Mortgage Crisis and the Future of Generally Accepted Accounting Principles." Finance and Accounting Monthly .17(2019):45-52. doi:10.19641/j.cnki.421290/f.2019.17.007.

[5] Fu Tongqing." Enron and SPE." Chinese Agricultural Accounting .01(2003):45-46. doi:CNKI:SUN:ZNKJ.0.2003-01-025.

[6] Tristano Sainati, et al."Special Purpose Entities in Megaprojects: Empty Boxes or Real Companies?." Project Management Journal 48.2(2017): doi:10.1177/875697281704800205.

[7] Paul Demeré, et al."The Economic Effects of Special Purpose Entities on Corporate Tax Avoidance." Contemporary Accounting Research 37.3(2020):. doi:10.1111/1911-3846.12580. 
[8] Ahlawat Sunita, Bellomo Danielle,and Ropp Kyle."Whether Sensible Business Tool or Deceptive Scheme to Conceal, the Special Purpose Entities Are here to Stay." Accounting and Finance Research 3.2(2014):. doi:10.5430/AFR.V3N2P77.

[9] Yao, X.Y. (2010), "The Success and Failure of Enron and the Application of SPE." Manager Journal 17(2010):66-66.

doi:CNKI:SUN:GLZJ.0.2010-17-059

[10] Yu, Q. (2005), "The Controversy and Reform of SPE Merger Principle from the Perspective of Enron Incident." 2005. Wuhan University, MA thesis.

[11]Qiao, W. (2002), "The Impact of SPE on Accounting Revealed by Enron Incident." The Chinese Certified Public Accountant 9(2002):5859. doi:CNKI:SUN:JKJS.0.2002-09-022.

[12] Lu, Jianqiao. "Accounting and Auditing in the PostEnron Era - A Review of the Sarbanes-Oxley Act of 2002 in the United States and Its Impact on Accounting and Auditing Development." Accounting Research 10(2002):33-42. doi:CNKI:SUN:KJYJ.0.2002-10-005.

[13]Hu, X. X., and Zhu, Y. C.. "A First Look at Special Purpose Entities (SPEs) Development in China." Science Association Forum (2nd Half) 04(2007):192-192. doi:CNKI:SUN:KXLT.0.200704-140. 